\title{
Apoptosis Regulator Bcl-2
}

National Cancer Institute

\section{Source}

National Cancer Institute. Apoptosis Regulator BC1-2. NCI Thesaurus. Code C18115.

Apoptosis regulator $\mathrm{Bcl}-2$ (239 aa, $\sim 26 \mathrm{kDa}$ ) is encoded by the human BCL2 gene. This protein plays a role in cellular survival. 